\title{
Faces of Muhammad: Western Perceptions of the Prophet of Islam from the Middle Ages to Today
}

\author{
John V. Tolan
}

Princeton: Princeton University Press, 2019. 328 pages.

John Tolan's Faces of Muhammad takes us on a journey through European perceptions of the Prophet of Islam. In European biographical literature, Muhammad took on various roles-initially almost exclusively malignant but gradually incorporating a positive assessment as well. The works of predecessors were integral to these writings, which meant that tropes developed over centuries had a durable quality. At the same time, reformist and revisionist thinkers reconstructed these tropes into polemical critiques of their own. In this way, exploring the reception of Muhammad since the twelfth century helps us understand modern discourses on religion.

The present title is written chronologically, explaining the background of each biographer, the role (or lack thereof) of any given religious thought at the time, and their primary motives. It employs the varying transliterations of "Muhammad" used at the time. Translations of the Quran often began with an introductory chapter on 'Mahomet'. Authors were writing to defend Christianity so the masses would not be theologically misled, to protect their people from Oriental vices, and to fend off fears of the nearby expanding Muslim empires. As times changed, Muhammad was used as an exemplar for what religious figures should $\mathrm{h}$ ave b ecome, e specially in 
light of the greater freedoms observed in the East by European travelers. The Qur'an and certain hadiths were claimed as source materials. Tolan includes artistic representations of the Prophet from each era and explains the historical and polemical significance of particular aesthetic details.

The first chapter ("Mahomet the Idol") summarizes who Muhammad was seen to be to the 'Saracens'. In Raoul de Caen's imagination, the Crusaders witnessed 'Mahummet' being worshipped as an idol in Jerusalem. Stressing the paganism of the Orientals was key to justifying the crusades. Tolan notes that this emphasis directly contradicted the knowledge that Christians must have had regarding Islam's strict monotheism. Late thirteenth-century art and literature often showed Christian knights emerging victorious in their battles versus Mahomet and his idolatry. Tolan comments that the antagonism Christians displayed here reflected their own insecurities regarding saint worship. The narrative they established encourages violent physical encounters with the Saracens rather than theological debate.

Chapter two ("Trickster and Heresiarch") transitions to the more widely-held medieval Christian views, namely that 'Machomet' corrupted Christianity with his heresy and tricked the masses of Arabia. Arguments were made that Machomet pursued prophethood as an alternative to a kingship he couldn't attain. Perhaps the most striking narration is Machomet informing his companions that on the third day after his death his body would rise, a prophecy fulfilled when his rotting corpse was "placed in an iron casket that was taken to a temple in Mecca that had magnets in the ceilings," there to fool the masses when (magnetized) it remained afloat and so "rose". Of course, Muhammad died in Medina and there is no historical mention of a floating casket, but this fiction took centuries to be corrected. Sergius, a Christian monk mentioned in Islamic sources as Bahira, identified prophethood in the future of Muhammad when he met him as a child, and in Christian sources is seen as an Arian or Nestorian Christian seeking revenge on the pope. Although Islamic sources only mention him once, European stories claim he was the source of most of "Mathomus's" corruption.

Chapter three ("Pseudoprophet of the Moors") focuses on the Muslims of Spain between the thirteenth and sixteenth centuries, and how their decline was theologically justified for Christians. The suppression of Muslims was warranted, in these arguments, in light of how Christians were treated in Muslim lands-although the parallels were few and far between, given 
that Christians were tolerated in Muslim lands under certain conditions while Muslims and Jews were driven out and killed. A new fable told in this time was the Prophet's corpse being desecrated by pigs that only left behind his foot after his 'Jewwess' mistress pulled it back (hence the 'tomb of Mahomat's foot'). The polemical tides shifted in the fifteenth century, when Nicholas of Cusa emphasized a unity of faith between Christian sects and Muslims, thus becoming "the first Latin Christian author to see the prophet's life and mission as positive" (90). Of course, the older tropes persisted, as when another author wrote that 'Mahoma' murdered an old man to marry his wife, Cadiga, whom he later killed to marry "a bevy of young beauties" (100). This smearing of the Prophet was utilized to attack other denominations, as when clergymen of one sect would declare the rival sect to be "worse than Mahomet."

The fourth chapter ("Prophet of the Turks") delves into intra-Christian theological debates, such as on the Immaculate Conception, which the Catholic Church made official doctrine in 1854. Supporters bolstered their position by citing the Islamic consensus on its veracity, thus validating Islam as purer and more authentic than certain sects of Christianity. The discourse thus shifted toward the idea of Islam being an imperfect sect of Christianity. The Catholics respond, with one work mentioning both Mahomet and Calvin together in hell. Some clergymen feared lay conversions to Islam, which justified their propagation of medieval legends. Writers such as Johann de Bry claimed that Mahomet was educated in science and in the scriptures of Jews and Christians, that he traveled to Africa and Spain, and was crowned King of Damascus.

Chapter five ("Republican Revolutionary in Renaissance England") details a revolution in European thought with Henry Stubbe's 1671 biography of the Prophet. Stubbe reconsidered European literature regarding Muhammad and began a paradigm shift which extolled his qualities and denounced the corruption of the Church. In 1689, when John Locke argued for equal citizenship rights in England, he also included 'Mahometans' under that rubric. Irish freethinker John Toland even went as far as to suggest that "Mahomet was a better Christian than Paul" (152). Some of these treatises would be published abroad in fear of retaliation.

Chapter six ("The Enlightenment Prophet") traces how authors of that period exalted the Prophet as a reformer, as they attacked the French Catholic Church. A 1705 treatise written in Arabic and Latin defended the tenets of Islam. The rise of the Muslim empires was attributed to their virtue and 
abstinence, such as the Islamic prohibition of alcohol and "seldom eating any flesh" (165). Tolan also explains the chronology of Voltaire's views on the Prophet, beginning with a negative impression and later revising his stance, with much of his diatribe serving as a stage to refute Paul.

Chapter seven ("Lawgiver, Statesman, Hero") discusses how Napoleon sought to emulate the Prophet of Islam. Napoleon famously began one of his letters to the Egyptian people with the theonymic phrase "In the name of God the Beneficent, the Merciful... he has neither son nor associate to his rule" (186). Even the alleged epilepsy of Mahomet is positively re-interpreted at this time, demonstrating his humanity (since great men like Caesar were also afflicted by it). Here Mahomet is coming to be revered as a statesman.

Chapter eight (“A Jewish Muhammad?") evaluates Jewish perspectives, such as that of Gustav Weil, who in 1842 became the first non-Muslim author to cite late Muslim scholarly works (217). The chapter ends by sketching the life of the renowned orientalist, Ignac Goldziher, who "revolutionized the study of Islam by Europeans" (225) and who had traveled the Islamic world studying with Muslim scholars (albeit for his own ends).

The final chapter ("Prophet of an Abrahamic Faith") highlights the theological arguments for declaring Muhammad a prophet of Christians as well, a controversial but increasingly accepted idea. The last section discusses the contributions of W. Montgomery Watt, who called on both Muslims and Christians to reform their doctrines that related to the other. He asked Muslims to relinquish their belief that biblical texts were distorted, calling it an unnecessary defense mechanism. A brief mention is made of Soviet Orientalist Liutsian Klimovich, refuted by Watt, who claimed "that Muhammad never existed, that he was an invention of later Islamic scholars" (253).

Tolan adroitly shows that there was never a single face of Muhammad in Europe. His use of medieval art and subsequent commentary is perhaps the most distinguishing aspect of the book. Most of the writers he engages had limited interactions with Muslims. Given the presence of Muslims throughout Europe today, it will be interesting to see the new 'Faces of $\mathrm{Mu}$ hammad' over the next century.

Moiz Mohammed

Graduate Student, Arabic and Islamic Studies

Georgetown University, Washington, DC 